\title{
Isaiah Berlin, Karl Marx, and the Enlightenment
}

\author{
David Leopold
}

\section{Introduction}

It is important to notice that part of my title is in italics. ${ }^{1}$ I am concerned here not with the entirety of Berlin's complex and lengthy engagement with Marx's thought, but rather with Berlin's first book: Karl Marx. His Life and Environment (1939). ${ }^{2}$ Written at an ambitiously early age - he was just thirty when it was published - it marked Berlin's first step into the history of ideas, the area of scholarship in which he would make his greatest impact. This monograph gives us an important snapshot of Berlin's early views on a range of topics, including Marx and the Enlightenment, which he would continue to pursue throughout his working life.

Karl Marx was commissioned in 1933 by H.A.L. Fisher, liberal grandee and Warden of New College, Oxford. Berlin would later develop a humorous and self-deprecating anecdote about just how many others had turned down the commission before he was finally approached. ${ }^{3}$ That story takes a number of forms, with the list of preferred alternatives growing with the telling, but none of the versions survives historical scrutiny intact. To kill the joke completely: it seems that Harold Laski, Frank Pakenham (later Lord Longford), and Sidney and Beatrice Webb, rejected initial approaches, and that others - including A.L. Rowse, and R. $\mathrm{H}$. Tawney - were discussed by the series editors and publisher but not approached. ${ }^{4}$ The brief that Berlin eventually inherited was to write fifty thousand words for a volume in the 'Home University Library of Modern Knowledge' published by Thornton Butterworth. The series had attracted some distinguished authors, including Leonard Hobhouse, Maurice Bowra, and Gilbert Murray, and its range of subjects was expansive; other titles included 'Belgium', 'The Literature of Japan', and - this might be my favourite - 'Nerves'.

\footnotetext{
${ }^{1}$ I am grateful to Henry Hardy for advice of various kinds, and Lucinda Rumsey for comments on an earlier draft.

${ }^{2}$ References to Karl Marx. His Life and Environment (henceforth KM) are to first (London: Thornton Butterworth, 1939) and fifth (Princeton: Princeton University Press, 2013) editions, respectively, with page numbers divided by a forward slash.

${ }^{3}$ See, for example, Ramin Jahanbegloo, Conversations with Isaiah Berlin (London: Peter Halban, 1992), 10-11; Michael Ignatieff tape reported Isaiah Berlin, Flourishing. Letters 1928-1946 (London: Chatto \& Windus, 2004), 67-68; 'Isaiah Berlin in Conversation with Steven Lukes', Salmagundi, 120 (1998), 70; and letter to Dennis Noël, 14 October 1996, Isaiah Berlin, Affirming. Letters 1975-1997 (London: Chatto \& Windus, 2015), 539.

${ }^{4}$ See Joshua Cherniss's research summarised at http://berlin.wolf.ox.ac.uk/information/az.html. Henry Hardy drily reports: 'When I mentioned these findings to Berlin, he was not terribly interested in abandoning the version(s) of the story he had become used to.'

${ }^{5}$ See list in KM 257-60/.
} 
Berlin would later claim 'I had never read a line of Marx, but I thought that Marx was likely to be[come] more rather than less important' in years to come. ${ }^{6}$ Berlin worked for five years on the book; produced a long typescript of some hundred thousand words, and, after the complicated and stressful dance familiar to all authors and editors, got away with submitting some seventy-five thousand of them. I am concerned here mainly with the published first edition, but both its forerunners and successors are of interest.

The Bodleian Library archives contain a manuscript, associated notes, a long typescript, a shorter typescript (with many manuscript additions), and several (some much annotated) proofs, for Karl Marx. The manuscript is a wonderful mixture of a just-legible hand, with a myriad of crossings-out (reflecting remorseless reformulation and reorganization of ideas), on a variety of, ink and coffee stained, paper stock (including, at one point, the reverse of a compliments slip from the Finchley Road branch of the Westminster Bank). The 'long typescript' is especially interesting; revealing what was cut to get within the (re)negotiated word limit (and what additions were made). ${ }^{7}$ Much of the cutting of the long typescript is judicious; not least, removing some repetition, and the resulting manuscript is perhaps improved as a result. ${ }^{8}$ The largest single amputation was an unremarkable section on Capital intended for the beginning of Chapter X (readers were still referred to Harold Laski's 'Home University' volume on Communism for Marx's specifically economic doctrines). Other omissions are more regrettable; including interesting asides on Heine's character and rejection of Judaism, and some intelligent speculation about the possible influence of Max Stirner on Nietzsche.

We also have the changes that Berlin made to the three later editions in his lifetime. ${ }^{9}$ The book was never out of print, and Berlin's revisions largely maintained its historical character. ${ }^{10} \mathrm{He}$ removed 'errors and obscurities', polished and refined the prose, but left substantive changes of interpretation to what he regarded as the necessary minimum. ${ }^{11}$ Two

\footnotetext{
6 'Berlin in Conversation with Lukes', 70.

${ }^{7}$ A clean copy, helpfully collated with the first edition (by Simon Toubeau), is available in 'The Isaiah Berlin Virtual Library' (online). The 'Virtual Library' also contains a note on 'The evolution of the text of Karl Marx', and a very useful 'Concordance' (by Nick Hall) cross-referencing the five editions.

${ }^{8}$ Berlin would later entertain this possibility, see letter to Henry Hardy, 13 November 1975, Berlin, Affirming, 12.

${ }^{9}$ See MSS Berlin 420-422. For discussion, see John Toews, 'Berlin's Marx: Enlightenment, Counter-Enlightenment, and the Historical Construction of Cultural Identities', Joseph Mali and Robert Wokler (edited), Isaiah Berlin's CounterEnlightenment (Philadelphia: American Philosophical Society, 2003), 163-176.

${ }^{10}$ The fifth edition, edited by Henry Hardy, happily identifies many references, corrects some remaining (factual) errors, and acknowledges certain weaknesses in Berlin's scholarly practice (for instance, his failure to identify quotations constructed from multiple sources).

${ }^{11}$ MSS Berlin 420 folio 57.
} 
additions might be mentioned. In 1960 (a reprint of the second edition) and 1963 (the third edition), Berlin introduced the theme of alienation (much discussed in recent scholarship) into the chapter on historical materialism, portraying Marx's theory of history as a narrative of human selfrealization. ${ }^{12}$ And, in 1978 (the fourth edition), Berlin allowed the possibility of a less 'rigorously deterministic interpretation' of Marx's theory, wherein freedom consists in mastering forces that had previously controlled us; as distinct from the earlier account of Marxian freedom as simply the perception of a fully determined necessity that continues as before. ${ }^{13}$

\section{The Marx Book}

Karl Marx is not, in my judgment, a great book; by which, to be precise, I mean that it is not a great book about Marx. Berlin's account of Marx's intellectual development, of his major theoretical views, and of his character, are all flawed in non-trivial ways.

Consider the following three concerns about Berlin's account of Marx's intellectual development. First, Berlin is too inclined to see Marx's work as having a 'massive architectonic quality', as being more systematic in both theoretical ambition and realization than it actually is. (Berlin was perhaps too quick to accept its overwhelmingly Hegelian character, and too sympathetic towards 'orthodox' readings of Marx's work inspired, in part, by Engels and Plekhanov.) ${ }^{14}$ Structurally, Berlin is, as a result, insufficiently attentive to the changing, contradictory, and unfinished character of Marx's work. Substantively, Berlin consequently fails to appreciate the extent to which Marx, at least in certain moods, shared what has been called Berlin's own 'empiricist resistance to the project of grand theory as such'. ${ }^{15}$ Second, having determined on Marx having a theoretical system, Berlin identifies that system as emerging bizarrely early. In one implausible formulation, Marx's 'final' intellectual transformation is said to have occurred before he left Paris in $1845 .^{16}$ (The proportions of the volume appear distorted by this emphasis on the earlier parts of Marx's life; halfway through the book Marx is still in his twenties.) And, third, Berlin is too keen on the picture of Marx as an isolated German thinker wholly uninfluenced by the thirty years he lived in London. 'So far as his intellectual development was concerned', Berlin writes, 'he might

\footnotetext{
${ }^{12}$ See, for example, KM /113-114; /117-121; /125-130; /132-134.

${ }^{13}$ See $K M / 130-2$.

${ }^{14} \mathrm{KM} / 146$. See also Werner Blumenberg's criticism reported in letter to Nicholas Jacobs, 14 April 1972, Isaiah Berlin, Building. Letters 1960-1975 (London: Chatto \& Windus, 2013), pp. 485-6; and the self-criticism in 'Preface' to the Fourth Edition, $K M / x x x$..

${ }^{15}$ G.A. Cohen, 'Isaiah's Marx, and Mine', Finding Oneself in the Other (Princeton:

Princeton University Press, 2013), 13.

${ }^{16} \mathrm{KM} 81 / 75$.
} 
just as well have spent his exile on Madagascar'. ${ }^{17}$ It is a brilliant quip but poor intellectual biography; the political, literary, and economic dimensions of British culture all had a significant, albeit complex, impact on Marx's life and work. ${ }^{18}$

I would also raise three worries about Berlin's account of Marx's theoretical views. First, Berlin implausibly maintains that Marx makes no moral complaints about capitalism; or, in a characteristically qualified formulation, that his later work reveals an 'almost complete absence' of moral argument or appeal to conscience or principle. ${ }^{19}$ Where modern commentators grapple with the apparent tension between Marx's critique of morality and his extensive use of moral criticism, Berlin largely ignores the latter (the widespread talk of 'theft' and 'robbery' in Capital go unacknowledged and unexplained). Second, implausibly convinced of Marx's determinedly necessitarian commitments, Berlin underestimates the role of human agency in the theory of history; seemingly forgetting that, for Marx, humankind make their own history, albeit not under conditions of their own choosing. ${ }^{20}$ Third, Berlin misrepresents Marx's political views in order to generate a convenient moral: the Bolsheviks are said to have borrowed Marx's early 'Blanquist' commitments, without noticing that he had subsequently and wisely come to reject them. ${ }^{21}$ It might be an attractive lesson, but the complicated and inconvenient facts do not support the Blanquist attribution to Marx. ${ }^{22}$

And, lastly, I venture three doubts about Berlin's account of Marx's character. First, Berlin abandons balance in order to portray Marx as impossibly splenetic in his relations with others. Indeed, Marx appears as an implausible psychological combination of external apoplexy and internal serenity; exhibiting 'an inner tranquillity' alongside 'his abnormal sensitiveness, his amour-propre, his vanity, his aggressiveness and his arrogance'. ${ }^{23}$ Second, Berlin misrepresents Marx's literary tastes as 'undistinguished and commonplace'. ${ }^{24}$ In fact, Marx was a voracious and

${ }^{17} K M$ 24/17. The following line was cut from the long typescript, but the thought remained: 'His education was fully completed before he arrived: life in England added nothing'. MSS Berlin 413 folio 28.

${ }^{18}$ See David Leopold, 'Karl Marx and British Socialism', W.J. Mander (edited), The Oxford Handbook of British Philosophy in the Nineteenth Century (Oxford: Oxford University Press, 2014), 402-422.

${ }^{19}$ KM 16/8

${ }^{20}$ Alluding to a quotation that Berlin was familiar with. See Karl Marx, 'Der 18. Brumaire des Louis Bonaparte', Marx/Engels Gesamtausgabe (Berlin: Dietz Verlag, 1985), Abteilung I, Band 11, 96; and Isaiah Berlin, 'Giambattista Vico and Cultural History', The Crooked Timber of Humanity (Princeton: Princeton University Press, 2013), 67.

${ }^{21}$ KM 165-66/174-75.

${ }^{22}$ See Richard N. Hunt, The Political Ideas of Marx and Engels. Marxism and Totalitarian Democracy, 1818-1850 (Pittsburgh: University of Pittsburgh Press, 1974), chapter 7; and Christine Lattek, Revolutionary Refugees. German Socialism in Britain, 1840-1860 (Abingdon: Routledge, 2006), chapter 3.

${ }^{23} K M 28 / 21$ and 38/31. See also Cohen, 'Isaiah's Marx', 10-11.

${ }^{24} K M 245 / 261$. 
imaginative reader, and an intelligent and creative adaptor, of an unusually wide range of European literature. ${ }^{25}$ Finally, by seeing him as lacking in moral outrage Berlin threatens to make little sense of either Marx's motivation or the life that he led. This objection was pressed gently at the time by A.D. Lindsay - then Master of Balliol College, Oxford - in a brief but interesting correspondence. ${ }^{26}$ Berlin was unmoved, but Lindsay's point remains astute. Berlin is widely held to be a master of Einfühlung, but in Karl Marx he failed to achieve that empathetic understanding of others different to ourselves, and perhaps, on this occasion, lacked the sympathy needed to do so.

\section{Contextualising Retreats}

These are not minor or peripheral failings, for all that they are only briefly sketched here. Confronted by such complaints from Marx scholars and others, one might be tempted by a contextualising retreat.

First, one might be tempted to situate Berlin's book as part of the 1930s reception of Marx's ideas in British, or Anglophone, culture. In that spirit, we might locate the work as part of a broader cultural phenomenon; namely, the more academic and middle-class reception of Marx, a movement which began in the 1920s in Britain but really gained momentum in the 1930s. ${ }^{27}$ The extent to which Berlin was swimming with the wider contemporary intellectual current is not often fully appreciated. E.H. Carr, A.D. Lindsay, Harold Laski, G.D.H. Cole, Sidney Hook, Raymond Postgate, John MacMurray, and others, had all published works about Marx ahead of Berlin. ${ }^{28}$ Or, in the same contextualising mood, we might pursue comparisons with particular contemporary volumes. The influence of Carr's biography Karl Marx: A Study in Fanaticism (1934) looks especially interesting; not least, because it contains something like the same character portrait of Marx as a psychologically unlikely combination of external rancour and internal calm. ${ }^{29}$ Berlin moderated his praise for Carr's volume before publication, and would later concede that

${ }^{25}$ See S.S. Prawer, Karl Marx and World Literature (Oxford: Oxford University Press, 1976).

${ }^{26}$ See letter to A.D. Lindsay, 31 October 1939, Berlin, Flourishing, pp. 296-98. I am grateful to Helen Burton (Special Collections, Keele) for supplying copies of the Lindsay side of the correspondence.

${ }^{27}$ See Ben Jackson, Equality and the British Left (Manchester: Manchester University Press, 2007), chapter 4; and Jamie Susskind, Karl Marx and British Intellectuals in the 1930s (Burford: Davenant Press, 2011).

${ }^{28}$ Those others include F.R. Salter, H.W.B. Joseph, J. Middleton Murry, Maurice Dobb, John Strachey, T.A. Jackson, and C.S.J. Sprigge.

${ }_{29}$ See, for example, Edward Hallett Carr, Karl Marx: a Study in Fanaticism (London: J.M. Dent, 1934), 61-62. 
he had been 'perhaps too deeply influenced' by Carr's work (amongst others). ${ }^{30}$

A second contextualising response might situate the book in the context of Berlin's own intellectual development. Joshua Cherniss, Arie Dubnov, and Michael Ignatieff, have all written accounts in something like this vein, confirming that there is much we can learn from such an approach. So understood, we might see Karl Marx as the ladder - to allude to a contemporary letter to Stephen Spender - which enabled Berlin to escape from the perceived 'futility' of certain wrangles in contemporary Oxford philosophy into the somewhat different world of the history of ideas. ${ }^{31}$ Or, we might think of the reading that Berlin did for this work as generating the storeroom of 'intellectual capital' on which he was to depend for the rest of his life. ${ }^{32} \mathrm{He}$ unearthed resources which supplied both the subject-matter (the Enlightenment and its critics, Russian intellectuals, and his 'hero' Alexander Herzen), and themes (the importance of ideas, the rejection of historical inevitability, the critique of utopianism, the character of historicism, and so on), of much of his later work. ${ }^{33}$ In more psychologising mode, we might also look for ways in which Berlin's efforts with this first book taught him about himself. Berlin regretted, in correspondence with Elizabeth Bowen, that he seemed to share Marx's distinctive combination of 'insensitivity' and a 'thin skin'. ${ }^{34}$ Whilst his biographer portrays the lessons as more vocational; Karl Marx taught Berlin that his talent was 'for synthesis, not for scholarship; the essay, not the monograph', and that the audience he cared about 'was the educated middle classes, not the specialists'. ${ }^{35}$

I will not pursue either of these broad contextualising strategies here. One worry is that they risk suggesting that Berlin has nothing much to say about his ostensible subject matter; that the significance of the book lies elsewhere - in what it tells us about Anglophone Marx-reception or Berlin's own intellectual development. In this latter spirit, David Caute describes Karl Marx as 'a book that would now be of only minor intellectual interest ... were it not the work of the young Isaiah Berlin'. ${ }^{36}$ I consider such a verdict as too hasty. I have said that this is not a great book about Marx, and that its interpretative flaws are many and non-trivial. Yet Berlin

${ }^{30} \mathrm{KM} / \mathrm{xxx}$. See also Berlin MSS 419 folio 127; and letter to Jennifer Williams c.30 September 1936, Berlin, Flourishing, p. 199ff. Carr subsequently described it as 'a foolish book' which he regretted attempting. See Jonathan Haslam, The Vices of Integrity: E.H. Carr, 1892-1982 (London: Verso, 2000), p. 53.

${ }^{31}$ Letter to Stephen Spender, 5 December 1932, Berlin, Flourishing, 43.

${ }^{32}$ Michael Ignatieff, Isaiah Berlin. A Life (London: Chatto \& Windus, 1998), 71.

${ }^{33}$ Jahanbegloo, Conversations With Berlin, 13.

${ }^{34}$ See letter to Elizabeth Bowen, before 27 September 1935, Berlin, Flourishing, 134. Interestingly, Marx is used serially as a comparison in Isaiah Berlin, 'L.B. Namier', Personal Impressions (Princeton: Princeton University Press, 2014), 131, 135, and 145.

${ }^{35}$ Ignatieff, Isaiah Berlin, 174.

${ }^{36}$ David Caute, Isaac and Isaiah. The Covert Punishment of a Cold War Heretic (Yale: Yale University Press, 2013), 16. 
does have genuinely interesting things to say about his subject-matter, and happily these include his account of Marx and Enlightenment ideas.

\section{The Enlightenment}

The word may only appear three times in the long typescript but the Enlightenment still forms a central thread in the book. It is typically treated as synonymous with what Berlin refers to as 'the rationalist position', or the views of 'the French rationalists'. ${ }^{37}$ David Hume and the role of empirical experience might get a mention, but Berlin comes close to adopting what might now be seen as a somewhat dated view of the Enlightenment as a single, somewhat cerebral, and overwhelmingly French, construction. Diderot, Condillac, and Helvétius, are all name-checked, but if a single individual could be said to have created this movement, we are told, it would 'unquestionably' be Voltaire. ${ }^{38}$ Both the content of this early portrait of the Enlightenment, and the role that it plays in this particular book, are of interest.

The account of the Enlightenment in Karl Marx has five main strands. First, this intellectual movement is characterised by its boundless faith in the power of reason to understand and change the world. ${ }^{39}$ Second, Enlightenment thinkers are said to hold that human beings are 'naturally good', and that reason exists equally in all (Condorcet is seemingly the paradigm proponent of this belief)..$^{40}$ Third, these writers believe that social and political outcomes would reflect that natural goodness were it not for the existence of artificial obstacles. These artificial obstacles, the source of all oppression and suffering, are said to stem from 'human ignorance' (including the supernatural beliefs sometimes fostered by those opponents of progress - priests, princes, and other privileged classes - who benefit from that ignorance).$^{41}$ Fourth, they hold that solutions to all properly formulated social and political questions can be identified by 'reason' and 'experience' (the same methods as had proved so successful 'in the hands of Kepler and Galileo'). ${ }^{42}$ Those solutions typically involved educational means; understood both narrowly, as in schooling, and broadly, as in the manipulation of the social environment. And, fifth and finally, that we are tending towards a rational society in which justice, equality, and happiness will become universal possessions. Indeed, history consists of the progressive removal of artificial obstacles, often by 'enlightened and benevolent government' seemingly well-placed to expose and eradicate them. ${ }^{43}$

\footnotetext{
${ }^{37}$ For example, $K M 41 / 34$ or 32/25.

${ }^{38} K M 46 / 39$.

${ }^{39}$ See $K M 42 / 35$.

${ }^{40} K M 42 / 35$.

${ }^{41} K M 42 / 35$.

${ }^{42} K M$ 42/35, 46/39.

${ }^{43} K M$ 42/35.
} 
Commentators have wondered about Berlin's sources here. Some, for example, have looked for, but not found much evidence of, Ernst Cassirer's influence.$^{44}$ However, I can offer no good reason to reject Berlin's own later claim that '[e]verything I knew about the Enlightenment came from Plekhanov'. ${ }^{45}$ That a Russian revolutionary should be Berlin's primary source might surprise some, but the attribution has textual support, and fits with his contemporary enthusiasm for the 'most brilliant and many sided' Plekhanov. ${ }^{46}$

The historical impact of Enlightenment ideas on European culture and society is said to be considerable ('hardly inferior', in Berlin's characteristic phrase, to that of the Italian Renaissance), ${ }^{47}$ and long-lasting (indeed, its influence 'continues into the present day') ${ }^{48} \mathrm{By}$ the nineteenth century this Enlightenment faith in the power of reason had became, in Berlin's words, 'the common inheritance of democrats of all shades and hues'.$^{49}$ In particular, all 'socialists and liberals, utilitarians and believers in natural rights', shared the language and faith of the Enlightenment, albeit perhaps with less confidence, less eloquence, and less naivety, than its original devotees. ${ }^{50}$

\section{The 'Counter-Attack'}

The Enlightenment also generated critics, and Berlin offers an account of the 'counter-attack' - which would subsequently evolve into his concept of the 'counter-Enlightenment' - that developed 'on German soil' around the cusp of the eighteenth and nineteenth centuries.$^{51}$ Hegel plays an important role in that narrative, forming part of 'a bold alternative' to Enlightenment ideas, which offered 'a less rationalistic view of nature and of the individual', and functioned to check 'the advance of empiricism from the west'.52

\footnotetext{
${ }^{44}$ Arie M. Dubnov, Isaiah Berlin, The Journey of a Jewish Liberal (New York: Palgrave Macmillan, 2012), 139-140.

${ }^{45}$ Michael Ignatieff tape quoted Joshua L. Cherniss, $A$ Mind and lts Time. The Development of Isaiah Berlin's Political Thought (Oxford: Oxford University Press, 2013), $31 \mathrm{fn}$ 154. See also 'Berlin in Conversation with Lukes', 73.

${ }^{46}$ KM 235/. See also Berlin, 'The Father of Russian Marxism', The Power of Ideas (Princeton: Princeton University Press, 2013). For his account of the Enlightenment, see G. Plekhanov, 'The Development of the Monist View of History', Selected Philosophical Works (Moscow: Foreign Languages Publishing, 1976), volume 1, chapter 1-3; and 'Essays on the History of Materialism', Selected Philosophical Works, volume 2, chapters $1-2$.

${ }^{47} K M 48 / 41$

${ }^{48} K M 41 / 34$.

${ }^{49} K M 48 / 41$.

${ }^{50} K M 48 / 42$.

${ }^{51} K M$ 48/42.

${ }^{52} \mathrm{KM}$ 48/42.
} 
Berlin is critical of many aspects of Hegel's thought. The latter's specifically logical doctrines and his account of the natural world are said to have been 'barren', and to have had a 'disastrous' impact. ${ }^{53}$ Berlin also distances himself from the purportedly politically conservative, even reactionary, character of Hegel's last years (in Berlin). ${ }^{54}$ However, Hegel's 'historicism of outlook' is portrayed as constituting a 'revolution in thought' which is broadly positive. It may have subsequently bred certain 'irrational and dangerous myths' - treating the state or race, for example, as 'superpersons exercising influence' - but the impact of this historicist outlook on the human sciences has, nonetheless, been 'very fruitful'. ${ }^{55}$

This 'historicism of outlook' rejected the Enlightenment extension of the empirical methods of the natural sciences to the human sciences. ${ }^{56}$ Mechanical models might enable you to control or predict the repetitive and non-dynamic behaviour of natural objects. However, to explain is to provide grounds, and something more like the notion of purposive activity is needed in order to grasp the meaning of human history. ${ }^{57}$ On Berlin's reading of Hegel, the subject of this purposive activity is variously 'the Idea or Spirit', whose development provides the unity of particular historical epochs, and the driving force and goal of the overall narrative. ${ }^{58}$ On this 'historicist' account, in order to understand a particular phenomenon we need, first, to place it in its wider social and cultural context, and, then, to locate that context in the wider developmental narrative in which it plays a constitutive role.

The organic development which constitutes and drives human history cannot, on the Hegelian account, be hurried or deflected. ${ }^{59}$ It unfolds at its own pace; not as a smooth progression, but driven by discontinuities, by the crises and conflicts of a process characterised as 'dialectical'. ${ }^{60}$ Berlin develops a contrast between what he thinks of as the Enlightenment approach to social change and what I would call Hegelian theodicy. To treat all the 'tragic waste and destruction' of human history as simple error, as artificial obstacles which are easily eradicated once knowledge has been obtained, is, on Hegel's account, profoundly mistaken. Wars and revolutions and all the rest, are rather to be understood as constituting part of the inner logic of historical development, they are explained and even justified by the progressive realization and self-consciousness of spirit. ${ }^{61} \mathrm{~A}$ parallel contrast applies to the Enlightenment view of what Berlin refers to as 'national, racial and social differences'; for Hegel, these differences are not irrational or contingent errors, but rather reflect 'some metaphysical

\footnotetext{
${ }^{53} K M 56 / 50$.

${ }^{54}$ See $K M$ 59/53, and 65-6/58.

${ }^{55}$ KM 56/50.

${ }^{56} K M 56 / 50$.

${ }^{57}$ See $K M$ 51-2/45-46.

${ }^{58}$ KM 54/48.

${ }^{59} K M 62 / 56$.

${ }^{60} K M 58 / 52$.

${ }^{61} K M$ 57-8/51.
} 
necessity', they are differences which are required for 'the development of the Idea'. ${ }^{2}$

Before turning to Marx, I offer a sceptical note. Berlin is not wrong to think of Hegel as responding to the Enlightenment, but other aspects of his account look more problematic. First, Hegel appears as if he were responding primarily to French rationalism, whereas he is better understood as engaging with German incarnations of Enlightenment thought (in the work of Wolff, Kant, Lessing, and others). Second, Hegel is sometimes portrayed as part of a brute 'counter-attack', as if his work offered a simple alternative to the Enlightenment, rather than something more like an internal critique. It seems odd to oppose Hegel to the Enlightenment faith in reason, given his insistence that reason creates and governs the world (creating it ex nihilo and governing it immanently). Moreover, when Hegel does consider the conflict between reason and tradition, or between universality and particularity, he always strives to transcend it (not to side with one side against the other). And finally, Berlin underestimates the extent to which Hegel thinks of his own work as presupposing the empirical writings of historians and others, taking over many of their results and showing them to be requirements of reason. The scale and importance of the resulting empirical strand in Hegel's writings and lectures should not be underestimated.

\section{Marx and the Enlightenment}

Berlin's account of the relationship between Marx and the Enlightenment has two distinct threads; call them the 'conceptual' and 'biographical', respectively. I start with the conceptual thread, in which Berlin outlines some affinities and tensions between Marx and Enlightenment thought.

Four main 'elements' of the Enlightenment picture are said to be 'clearly apparent' in Marx's work. ${ }^{63}$ First, the rationalist threads in Marx's thought include his commitment to the power of reason to understand social phenomena; we are told that Marx 'believed in the complete intelligibility of the process of social evolution'. ${ }^{64}$ Second, Marx also shared the Enlightenment rejection of superstition and supernatural explanations, and had a 'passion for exposing irrationalism and myths in every shape and guise'. ${ }^{65}$ Third, Marx remained, in Berlin's phrase, a 'perfectibilian'; that is, he 'believed that society is inevitably progressive, that its movement from stage to stage is a forward movement, that each successive stage represents development, is nearer the rational ideal than its precursors' ${ }^{66}$ Fourth, and finally, Marx's hostility towards institutions and movements

\footnotetext{
62 KM 59/53.

${ }^{63} K M 35 / 28$.

${ }^{64} K M 35 / 28$.

${ }^{65} K M 63 / 56$.

${ }^{66} K M$ 35/. Later editions have stylistic changes. See $K M / 29$.
} 
founded 'on some traditional or emotional basis' (not least, nationalisms), led him to underestimate 'their actual influence'. ${ }^{67}$

In addition, Berlin identifies four main contrasts between Marx and Enlightenment ideas. First, he suggests that Marx 'did not, indeed, believe in the power of rational argument to influence action' ${ }^{68}$ As formulated, that looks too strong; after all, Marx spends thousands of pages trying to influence the behaviour of others by rational argument. However, he does hold that there are objective as well as subjective conditions for ideas being translated into successful action. And even where the objective conditions exist, Marx thinks that rational argument alone is not always effective given the power of vested interests and 'ideology'. Second, Marx is described as breaking with the Enlightenment view that humankind is 'fundamentally generous and just' ${ }^{69}$ The extent to which this is, or is not, the case, depends on the wider social, and especially economic, environment in which humankind is circumstanced. ${ }^{70}$ Third, social transformation, for Marx, cannot occur, as the 'Encyclopedists' would have us believe, 'overnight'. ${ }^{71} \mathrm{He}$ recognised that the past was a weightier obstacle than often imagined, and that generations would be needed before its baggage could be overcome. Fourth, and finally, Marx denied the smoothly progressing account of human history, emphasising rather its 'contradictory character'. ${ }^{72}$ Capitalism, we might say, increases the social suffering of humankind, as well as bringing us closer to the possibility of overcoming that suffering.

In addition to this conceptual thread, Berlin offers a biographical account. He identifies the source(s) of Marx's early exposure to Enlightenment ideas, and assesses their impact on his intellectual development.

In the literature, Marx's father-in-law is often treated as the central early conduit for Enlightenment ideas, but Berlin makes little of that connection. Eduard Gans and Ludwig Feuerbach are mentioned as possibilities, but again with little enthusiasm. Instead, it is Marx's father - Heinrich (originally Herschel) Marx - who is identified as the earliest and strongest Enlightenment influence. We are told that Marx's father was variously: a 'disciple of Leibnitz and Voltaire, Lessing and Kant'; a believer along 'with Condorcet' that human beings are 'both good and rational' by nature; and as quietly convinced that, as 'unnatural obstacles' were removed, a more

\footnotetext{
${ }^{67} K M 178 / 189$.

${ }^{68} K M 35 / 28$.

${ }^{69} K M 128 / 138$.

${ }^{70} K M 128 / 138$.

${ }^{71} \mathrm{KM} 86 /$. Later editions have 'more extreme among the Encyclopedists'. This is one of several passages where the holder of the relevant views is not initially obvious. Henry Hardy records an endearing anecdote (from Mary Fisher) concerning Isaiah's parents. Shortly after publication, Mendel read the book aloud to Marie, who would frequently interrupt to ask 'is that Marx or is it Shaya [a diminutive for Isaiah - DL]', to be reassured 'No no - that it is only Marx: it is not Shaya'. KM/xi.

${ }^{72} K M / 28$. See also, for example, $K M$ 215/228.
} 
rational and dignified mode of life was being progressively realized in the world. ${ }^{73}$

Berlin emphasizes the positive impact of Enlightenment ideas on Marx's intellectual development. In particular, this Enlightenment influence is said to account for the realistic and concrete quality of his thought, giving Marx an early taste for both 'lucid argument' and 'an empirical approach'. ${ }^{.74}$ In this context, Berlin emphasises the empirical strand in Enlightenment rationalism, apparent in its rejection both of innate knowledge and the validity of certain appeals to authority. This account of Enlightenment influence is important, not least because these characteristics are at the heart of Berlin's praise for Marx's achievement.

Talk of praise might surprise some readers. Perhaps because of Berlin's subsequent intellectual evolution, and a widespread conflation of Marx with Marxism, Karl Marx is often assumed to be far more hostile towards its subject than it actually is. ${ }^{75}$ Arie Dubnov, for instance, maintains that '[i]t was obvious that the author ... strongly believed that Marx's ideas should be entirely dismissed" ${ }^{76}$ Yet such an unqualified and negative verdict is hard to square with Berlin's extensive praise for Marx's achievement. A few examples will suffice. Berlin tells us that '[t]he true father of modern economic history, and, indeed, of modern sociology, in so far as any one man may claim that title, is Karl Marx'. ${ }^{77}$ In Capital, Marx demonstrates 'a new and revolutionary method of historical writing and political interpretation' which constituted 'the most formidable, sustained, and elaborate indictment ever delivered against an entire social order, ${ }^{78} \mathrm{His}$ use of 'blue books and official reports', in particular, is said to have 'revolutionised' the 'technique of social research'. ${ }^{79}$ In addition, Marx's class analysis is described as 'a remarkably original classification for its time'. ${ }^{80}$ And he is acclaimed as an acute political observer, whose journalism could be 'sharp, lucid, realistic, astonishingly modern in tone' ${ }^{\prime} 1$ More generally, Berlin notes that modern readers are liable to underestimate Marx's achievement precisely because his ideas look so familiar; Marx's economic and sociological insights have become part of 'the permanent background of civilised thought' and consequently can

\footnotetext{
${ }^{73} K M$ 35/26-27. Note the intermingling of French and German authors here.

${ }^{74} K M 36 / 29$.

${ }^{75}$ As noted by Terrell Carver, 'Berlin's Karl Marx', George Crowder and Henry Hardy (edited), The One and the Many. Reading Isaiah Berlin (New York: Prometheus Books, 2007), 31-32. See also letter to Mark Lilla, 13 December 1993, Berlin, Affirming, 474. On distinguishing Marx and Marxism, see Duncan Kelly, 'The Political Thought of Isaiah Berlin', British Journal of Politics and International Relations, 4/1 (2002), 25-48.

${ }^{76}$ Dubnov, Isaiah Berlin, 132. My emphasis.

${ }^{77} \mathrm{KM} 138 / 147$.

${ }^{78} K M 27 / 20$.

${ }^{79} K M 219 / 233$.

${ }^{80} K M$ 215/. Later editions add 'fruitful' to 'original'. See KM /228.

${ }^{81}$ KM 24/. Later editions add 'mordant'. KM /18.
} 
easily go unnoticed. ${ }^{82}$ That complex impact is presented as contradicting a Marxian claim about the importance of ideas, but that so much of what Marx argued for is nowadays taken for granted, Berlin writes, is 'a mark of genius', and there is no doubt that Marx was 'richly endowed' with genius. $^{83}$

As well as being directly responsible for many of the positive threads that Berlin identifies in Marx's work, this early Enlightenment influence also plays a valuable prophylactic role. It helped Marx to 'preserve a measure of critical independence' in the face of philosophical fashion. ${ }^{84}$ More precisely, this early Enlightenment influence explains the relatively minor impact, on Marx's work, of the metaphysical systems (of Hegel and Fichte) that Berlin associates with German Romanticism. Hegel, of course, remains a huge influence, but that early Enlightenment formation gave Marx enough intellectual independence to save him from the 'total surrender' to the 'fascination' of Hegelianism, a fascination which 'undid so many of his contemporaries'. ${ }^{85}$ In particular, Marx did not share what Berlin calls Hegel's 'reckless and contemptuous attitude' towards scientific research, and he (that is, Marx) strove 'to follow the direction indicated by the empirical sciences, and to incorporate their general results'. ${ }^{86}$ Indeed, even where the structure of Marx's thought is said to be Hegelian, plenty of non-Hegelian content shines through. ${ }^{87}$

Again (as with the discussion of Hegel), a sceptical note seems merited. Berlin is surely right, not only to identify a realistic, lucid, and empirical, strand in Marx's work, but also to see its early appearance as part of the explanation of the young Marx's resistance to Hegel's metaphysics. ${ }^{88}$ However, Berlin's enthusiasm for the narrative about French Enlightenment and Teutonic counter-attack remains problematic.

The suggestion that Marx's father was the early conduit for this Enlightenment influence is attractive. Not least, it avoids the offensive implication that enlightenment, more generally, could only have come from outside the family, typically in the form of his Gentile father-in-law. However, there is little hard evidence to support the suggestion. Berlin is at his ventriloquizing best in turning Heinrich into the Enlightenment personified, but the 'probably's' that pepper his prose at this point implicitly

${ }^{82} K M 138 / 148$. See also $K M 249 / 265-6$.

83 KM 138/148.

${ }^{84} K M / 29$. First edition omits the elucidating 'critical', $K M 36 /$.

85 KM 36/29.

86 KM 137/146.

87 See KM 63/56, 136-7/146.

${ }^{88}$ On Marx's critique of Hegel's metaphysics, see David Leopold, The Young Karl Marx. German Philosophy, Modern Politics, and Human Flourishing (Cambridge: Cambridge University Press, 2007), 46-56. 
acknowledge the speculative character of the reconstruction. ${ }^{89}$ This is not to deny that Heinrich had an intellectual influence on his son, just to resist this attempt to cast him as the leading Enlightenment source in the absence of more concrete evidence of Heinrich's actual views (evidence, to be clear, that we do not really have).

More importantly, we might doubt that the relevant characteristics - Marx's realism, lucidity, and enthusiasm for empirical enquiry - reflect much direct influence of French Enlightenment thought. We now know rather a lot about the young Marx's intellectual formation; due, in part, to the survival of 'excerpt-notebooks' which reveal much of what he read, and the extent of his engagement with it. ${ }^{90}$ And these materials, whilst conveying no extensive contact with Voltaire, Condorcet, and the rest, do raise other possibilities. First, they raise the possibility that we don't need sources which are very closely identified as Enlightenment ones because the relevant characteristics might be found elsewhere; for instance, in the writings of the contemporary British and French historians that Marx was reading in the early 1840 s (Tocqueville say, or Thomas Hamilton). ${ }^{91}$ Second, they raise the possibility that, if you were still determined on the Enlightenment being the answer, you might do better to emphasise Scottish and German over French varieties. The young Marx variously read and made excerpts from Kantian philosophy (courtesy of Karl Rosenkrantz), from Hume's writings on human nature (collected in a German edition), and Smith's Wealth of Nations (in French translation). ${ }^{92}$ Berlin would later allow that 'English' (in reality, mainly Scottish) political economy might have reinforced Marx's enthusiasm for 'such naturalistic explanations as could be supported by the evidence of critical observation'. ${ }^{93}$ However, given the timing, we might prefer to treat such writings as the source rather than the reinforcement. Indeed, both these (Scottish and German) alternatives have solid, rather than speculative, connections to Marx's early intellectual formation.

\section{Concluding Remarks}

My portrayal of Berlin's understanding of Marx and the Enlightenment might surprise some readers. It is interestingly unlike what we might call

\footnotetext{
${ }^{89}$ For example, 'he probably', $K M 32 / 25$; and, for variation, 'it is not improbable', $K M$ 34/26. On Berlin's ventriloquizing, see Stefan Collini, English Pasts. Essays in History and Culture (Oxford: Oxford University Press, 1999), 197.

${ }_{90}$ Sources known but (effectively) not available to Marx scholars in the 1930s.

${ }^{91}$ See Marx/Engels Gesamtausgabe (Berlin: Dietz Verlag, 1976), Abteilung I, Band 2, 146; and Marx/Engels Gesamtausgabe (Berlin: Dietz Verlag, 1976), Abteilung IV, Band 2, 266-275.

92 See Marx/Engels Gesamtausgabe (Berlin: Dietz Verlag, 1976), Abteilung IV, Band 1, 213-33, and 277-292. And Marx/Engels Gesamtausgabe, Abteilung IV, Band 2, 332-387. ${ }^{93}$ KM 87/81.
} 
the 'received' account of these matters, an account which involves a more hostile portrait of both the Enlightenment and Marx's relation to it. ${ }^{94}$

On this received account, Berlin advances three claims about Marx and his relation to the Enlightenment: first, that Marx was an archetypal Enlightenment figure; second, that the Enlightenment character of Marx's thought was not in its favour, since it was the source of certain significant flaws in his doctrines; and third, that the most important of these doctrinal flaws was Marx's denial of the truth of 'value pluralism' in its Berlinian form; namely that (for complex conceptual and empirical reasons which we need not dwell on here) it is not possible fully to combine all values (either in thought or reality). ${ }^{95}$ To put matters dramatically - and allowing the additional Berlinian assumption that authoritarianism is linked with the denial of value pluralism - Marx is offered up as confirmation of the tendency of Enlightenment monism to slide into political despotism.

I have reservations about the accuracy of the received account (of the Enlightenment and Marx's relation to it), and about the unqualified attribution of that received account to Berlin. However, here I insist only that, if these are Berlin's views, then he came to them somewhat later in his intellectual evolution than the period under consideration. Certainly, none of the three claims of the received account are much evident in the first edition of Karl Marx. First, Marx is not portrayed as an archetypal Enlightenment thinker in this book. Rather, despite signs of its influence in his work (his view that social phenomena are open to explanation; his rejection of irrationalism; and so on), Marx breaks with Enlightenment thought (in his scepticism about the ability of reason alone to change the world; in his denial of the natural goodness of humankind; and in his appreciation of the weight of the past and the complexity of historical progress). Second, the Enlightenment influence on Marx's thought is often identified as positive. In later writings, Berlin's portrayal of the Enlightenment can look too dark, but here it also generates a culture of unsentimental 'humanism', in which intellectual 'courage' and 'disinterestedness' are viewed as virtues. ${ }^{96}$ The Enlightenment, we are told, helps explain what is best in Marx's work: namely, its realism, clarity, and empirical insight (all part of his 'genius'). And the Enlightenment is said to have inoculated Marx against the contagious fascination of Hegelian metaphysics, saving him from the ignominious historical fate of ending up a minor left-Hegelian (like Bruno Bauer or Arnold Ruge). And third, whatever the doctrinal and other flaws in Marx's work, Berlin does not, at this time, clearly identify Marx as rejecting the truth of value pluralism. (Rather it is Marx's supposedly deterministic account of history, underestimation of nationalism, and, above all, denial of the importance of

${ }^{94}$ The 'received' account is a composite drawn from the literature. See, for example, George Crowder, Isaiah Berlin. Liberty and Pluralism (Cambridge: Polity, 2004), 115 and 129; and John Gray, Isaiah Berlin (London: Harper Collins, 1995), 75 and 94-5.

${ }^{95}$ On Marx and value pluralism, see Cohen, 'Isaiah's Marx, and Mine', 12.

${ }^{96} \mathrm{KM} \mathrm{48/41.}$ 
ideas, which draw Berlin's critical ire.) Nor, on reflection, should this really surprise, since Berlin's own account of value pluralism remained underdeveloped at this time. This is not, of course, to say that there is no adumbration whatsoever of these ideas here, but Berlin had not yet clearly formulated the sin of rejecting the truth of value pluralism, let alone decided who was guilty of it. ${ }^{97}$

I conclude with historical and evaluative lessons to be drawn from this engagement with Berlin's Karl Marx. The historical lesson might look obvious, but, if so, note that this does not prevent it from being widely ignored in the literature. In brief, it is a mistake to assume that Berlin in the 1930 s held the same views as he did, say, in the 1950s and 1960s. The war, and then the cold war, might well mark significant shifts both in Berlin's ideas, and the emphasis that he felt it appropriate to give them. The evaluative lesson is a little less general, but still important. This may not be a great book about Marx; Berlin's account of Marx's intellectual development, theoretical views, and character, look to be flawed in a variety of non-trivial ways. However, there remains much of interest in the volume, and its account of Marx does not deserve contextualising erasure. Not least, Berlin's early understanding of Marx's relation to the Enlightenment strikes me as more complex, more plausible, and more interesting, than the received account would allow. The Enlightenment looks less dark, and Marx's relation to it is both more positive and more nuanced. The Enlightenment here narrowly maintains its claim to being one of the better and more hopeful episodes in human history, and Marx stands in a complex relation of affinity with, and rejection of, its central components. Indeed, its impact on him is largely beneficial. The Enlightenment not only inoculated Marx against certain Hegelian excesses, but also provided the source of much of what is judged best in his writings - their realism, clarity, and empirical insight.

\footnotetext{
${ }^{97}$ Indeed, some identify Marx as a possible source of elements of Berlin's idea of value pluralism. Crowder notes that Marxian 'dialectical' progressions often pit good against good; and Cherniss observes (following Stuart Hampshire) that Marx's account of social conflict suggests conflicts between values. See Crowder, Isaiah Berlin, 23-24; and Cherniss, A Mind and its Time, 51-52.
} 